\title{
Role of Journalists' Gender, Work Experience and Education in Ethical Decision Making
}

\author{
Nafise E. Motlagh ${ }^{1}$, Md Salleh Bin Hj Hassan ${ }^{1}$, Jusang Bin Bolong ${ }^{1} \&$ Mohd. Nizam Osman ${ }^{1}$ \\ ${ }^{1}$ University Putra Malaysia, Malaysia \\ Correspondence: Nafise E. Motlagh, University Putra Malaysia, Malaysia. E-mail: nafise.motlaq@gmail.com
}

Received: April 22, 2013 Accepted: May 16, 2013 Online Published: May 20, 2013

doi:10.5539/ass.v9n9p1

URL: http://dx.doi.org/10.5539/ass.v9n9p1

\begin{abstract}
This research was conducted to determine the role of journalists' gender, work experience and education in their ethical decisions in uncertain situations. The instrument used was structured and self-administered questionnaire. This quantitative descriptive study selected 231 full-time Malaysian journalists from five highly-circulated newspapers in April 2011. Non-probability sampling (convenience) was applied to collect the data and to estimate the characteristics of the whole population. The results showed that more than half $(51.8 \%)$ of the 228 journalists made unfair decisions about seven short presumptive statuses, which were designed based on the Malaysia National Union of Journalists' codes of ethics. According to this study, neither gender nor journalism education made any difference in journalists' ethical decisions. The findings also showed the more work experience the journalists had, the more fair decisions they made in uncertain situations.
\end{abstract}

Keywords: journalism ethics, gender, work experience, journalism education, ethical decision-making, media ethics

\section{Introduction}

Journalism ethics is a branch of philosophy concerned with the actions that are morally permissible and those that are not. In Journalism, ethics is important because it controls what gets published. Media ethics help media workers in deciding what is right, and how to choose the best from several alternatives. "Media ethics" constitutes a normative science of conduct and must therefore apply voluntarily.

Professional journalists should be honest, truthful and reveal all crucial facts. They must be sensitive at times of grief and trauma. They should never suppress information or deform them and never allow personal believes or commitments to alter the story. As Hoo and Yeing (2010) said, journalists play an important role in reporting the news to the public for greater understanding on latest issues. Their responsibility is to gather information and to report it to the public. They have to act ethically and be professional in reporting news exactly and correctly. Although journalists may not consciously be distorting their reporting, they may, nonetheless, be reporting the events in a manner conducive to the interests and values of a particular section or society.

There are many examples regarding to the lack of ethics in journalism such as giving wrong information, deception, and conflict of interests. These practices not only upset or harm others, but also can make people stop trusting journalists. Journalists are the society's delegated recorders of reality. They are given access to people and events way beyond that of the average member of the public, but the unspoken condition is that they should report the truth back. They should not allow their account to be influenced by their personal biases, by conflicts of interests, or by monetary inducements. They have to try to represent any situation as fairly and accurately as they can. They have to treat the public with respect. It is on this basis that they exercise power. If they violate, they risk losing their credibility and reputation; heavy penalties from which it is hard to recover and colleagues and employers are dishonored too (Tanner, Phillips, Smyth \& Tapsall, 2005).

Nowadays, many companies and associations in different fields including journalism try to conduct their employees based on the relevant codes of ethics. According to Kaptein (2004) fifty-eight percent of the 100 largest companies in the world employ ethical codes. Codes articulate ethical boundaries of an organization what is acceptable and what is not? (Stevens, 2008). Respect for truth and the public's right to information are overriding principles for all journalists. In pursuance of these principles, journalists commit themselves to ethical and professional standards. Codes of ethics provide some guidelines to help them in decision-making. Without 
them, journalists' actions may be random and unguided. The earliest journalistic code of ethics drew up in 1923 by the American Society of Newspaper Editors.

This study was conducted in Malaysia; a developing country located in South-East Asia. In Malaysia, journalists are guided by National Union of Journalism (NUJ) codes of ethics, which was formulated in 1962. The NUJ is the only organization of working journalists in the country which represents the industrial, social and welfare interest of some 1,400 journalists. NUJ defined clearly what journalists "should" and "should not" do within 7 principles: Some important aspects such as truth, professional discretion, and the objectivity in media are among the values, clearly stated in NUJ codes of ethics. The main purpose of this study is to determine the role of gender, journalism educating and experience in journalists' ethical decision making. The Research questions are as follows:

1) How well Malaysian journalists make decision in uncertain ethical situations?

2) Is there any difference in ethical decision making based on their gender and education background?

3) What is the relationship between ethical decision-making and their work experience?

\section{Literature review}

Philosophers have been discussing ethics for more than 2500 years. Most university students are introduced to the writings of the early Greek philosophers and thinkers like Plato, Aristotle and Socrates. They may also study the writings of early English philosophers such as Thomas Hobbs, John Locke, James Mill, Rousseau and Immanuel Kant, an enormously influential philosopher of the Enlightenment. Ethics has been defined as "the conception of what is right and fair conduct or behavior' (Joyner \& Payne, 2002). Journalism ethics raised after the pressure of government regulation of media mounted. Journalism industry leaders responded with efforts to professionalize. They try to educate professional journalists rather than cede control of media to a government agency.

\subsection{Journalism Codes of Ethic}

A code of ethics is usually considered as one of the key elements of true professions. Parallel to the history of the $20^{\text {th }}$ century, professionalization of journalism runs the history of professional codes of ethics, and even though journalists disagree on whether a code should be in place or not, they share a sense of being ethical, which in turn legitimizes their claims to the position as free and fair watchdogs of society (Deuze 2005). The official rationale underlying codes of ethics is to assure the highest standards of conduct, protect clients, and contribute to the public welfare (Rothman, 1984).

Despite problems and dilemmas surrounding ethical codes, ethics is to be understood as inseparable from good journalism. As Sanders (2003) says: "Thinking about ethics is to think about what journalism is and what journalists do." Thinking about ethics is to think about the very foundations of journalism, about its roles and responsibilities, about its nature. Unethical journalism is both an indicator and a source of journalism's identity crisis. As Pyle (2000) pointed out, the demands for profits "seem increasingly to override the ethical and professional standards of reporters and their editors".

Schwartz (2000) contended that codes are ineffective systems of control, but in a later study concluded that they are effective in some situations and failed in others. Wotruba, Chonko and leo (2001) discovered that the usefulness of codes of ethics by managers as a tool for guiding behavior and decisions is strengthened as managers become familiar with the specific contents and intentions of codes. However, other studies (Fisher, 2001; Somers, 2001; Chonko, Wotrube \& Loe, 2003; Adam \& Rachman-Moore, 2004; O'Dwyer \& Madden, 2006; Vitell \& Encarnacion, 2006) provided evidence of code effectiveness in terms of playing a role in impacting employee behavior and perceiving right ethical actions. A more recent study by Stevens (2008) indicated that corporate ethical codes can be effective instruments for molding employee behavior and guiding ethical decision-making when they are embedded in the organizational culture and communicated effectively.

Wong (2004) claims that journalists in Malaysia tend to support the ruling party during elections. In fact, this research reveals the ignorance of an important code of ethics in journalism, which is "objectivity". Based on a survey, done by Motlagh and Narimah Ismail (2009), 42\% of journalists in Bernama (Malaysia National News Agency) had never read the Malaysian journalism codes of ethics. The problem is neglecting the journalism ethics damages the trust of the readers and audience.

Faridah Ibrahim (2010) believes that Malaysian journalists have learned how to determine the morality of an action by its consequences. Kaur and Halimahton (2003) assert that Malaysian journalists' awareness of their respective code of ethics is only average and even though the journalists are aware of ethical principles, there is 
still a lot of room for improvement for the practice of ethics.

\subsection{Gender, Journalism Education and Work Experience}

Codes of ethics are not the sole factor influencing ethical decisions. Ethical decisions are also dependent on the personal values of the decision-makers. Various journalism ethics studies have attempted to link internal influences such as personal values and beliefs, education, journalism training, age and gender with moral decision-making (Breed, 1955; Beam, 1990; Weaver \& Wilhoit, 1996; Graber, 1997; Valenti, 1998; Voakes, 1997; Wulfemeyer, 1990).

Some believe that women and men have different values and ethical systems. Stereotypically, men tend to focus on action, problem solving, and self-assertion while women tend to be more concerned about emotional connection, community building, and a concern for others. Some studies have found that men and women, in relation to their jobs, do not differ that much in terms of their values and ethical systems. They believe that occupational experiences override the socialization theory that men and women fall into gender roles (Mason \& Mudrack, 1996). In Mason and Mudrack's study of both full-time employed men and women and unemployed men and women, it was found that gender differences in ethical orientation existed in the full time employed group and did not in the non-employed group. It was also found that in the employed group, women had a more ethical response than men.

Cohen et al. (1998) also conducted a study to investigate the effect of gender on ethical intentions, ethical orientation and ethical evaluation of potential accounting recruits who were accounting, other business or liberal arts undergraduates. The results showed that women tended to be more ethical than men. Women judged questionable actions as less ethical than the men did. They also found that women had a stronger sense of duty and a greater emphasis on justice.

In an interesting study which investigated how ethical beliefs are related to age and gender, it was discovered that in the younger age groups females scored higher ethically than males, while in the older age group males had a slightly higher ethical score (Peterson, Rhoads \& Vaught, 2001). It was also concluded that as managers get old they become more ethical. Expanding on the viewpoint that women and men do in fact make different ethical decisions, it would be beneficial for businesses to use this data to make their climate more sensitive to the ethical concerns of both genders (Weeks, Moore, McKinney \& Longenecker, 1999).

Boone and MacDonald (2009), examined the issues of gender, ethics and decision-making as demonstrated by selected professionals at a cable news network. The research studies the journalists' decision-making processes to determine if there is an ethical difference between men and women. Both males and females identified as having decision-making responsibility within a cable news network were interviewed. A structured set of questions was employed and the responses were used to identify the processes they employed in applying both personal and organizational ethics to their decisions.

Kohlberg (1981) specifically examined the ethical decision-making of undergraduates and determined that moral development occurred in stages in association with educational and intellectual development. He determined that the third stage, post-conventional, does not occur until after the age of 20 and those individuals understand and basically accept society's rules. However, sometimes those rules come in conflict with general moral principles; thereby those in the post-conventional stage will judge by principles rather than the rules. Laban and Kovacic (2007) also found out there is a correlation with journalism education and journalist's better understanding of professional competence. Based on their studies, editors' views on the importance of basic social sciences knowledge and communication theory knowledge significantly correlate with their views on professional competence of journalism studies graduates in comparison with journalists with some other education as well as with their views on the importance of formal education and journalistic experiences.

\subsection{Media in Malaysia}

In most developing nations, the roles of the media have been reoriented and adjusted to local needs. Much of the media's role, particularly the mainstream media, is tied closely to government objectives. In Malaysia for instance, the mass media (especially the mainstream) are not only required to inform, educate and motivate the masses towards the developmental goals stipulated by the government, they are also expected to go along with the government's policies in order to survive in the media business (Ibrahim, 2010). She asserts in her studies that, while the news media across developing nations look at media laws and regulations as significant leverage to hold them accountable, a majority of Malaysian journalists prefer to work from within in the form of self-censorship. Ethically conscious journalists also feel the need for voluntary recognition and acceptance of responsibility to provide the kind of information that will not rupture the social fabric and cause unrest among 
the people.

A study by Berkowitz, Limor, and Singer (2004) provides support for the assumption that the social or national context of news-making in Asia is important in shaping journalism ethical decisions. So, if there are 'Asian' values in journalism, they must appear in reporting practices. It means the social and national values of each Asian country might affect its journalists' decisions in uncertain situations. Meanwhile Banerjee (2002) believes that it is only in a liberal democratic society where media have some amount of independence, that one can expect media practitioners and journalists to uphold professional standards and ethics. In other words, a journalist operating in an environment with strict media control cannot be judged for his ethical practices. Hence, he cannot be expected to sacrifice everything, including his life, for the sake of moral and ethical beliefs.

\section{Method}

The instrument used in the present study was structured and self-administered survey questionnaire. Structured questionnaire was chosen because it enables the researcher to collect data from a relatively extensive number of respondents in given time and geographical constraints. The respondents of study were selected in April 2011 from Malaysian journalists who worked full-time in 5 highly circulated newspapers, which are "Harian Metro", "The Sun", "Star", "Berta Harian" and "New Strait Times (NST)".

In this study, Yamane's (1967) formula was used to calculate the sample size. Based on this formula, 39.89 percent of the population was chosen as the sample, including 231 full-time journalists. Before distributing the questionnaire to the respondents, a pre-test was conducted. The pre-test helped the researcher to modify and rearrange some of the questions and to examine the internal consistency of items (questions).

After the data collection, a number of procedures were carried out to organize the data such as entering them systematically in the computer, scoring the data accurately, and applying normality test for main variables. Then, appropriate statistical procedures were used for each objective such as; descriptive statistics, cross tabulation, Chi-square test, Pearson correlation, sample independent t-test and multi regression test.

\section{Results and Discussion}

\subsection{Respondent Demography}

The profile of respondents was presented in terms of age, gender, level of education, field of study, work experience and job position. The results are summarized in Table 1. According to Table 1, the respondents were rather young as the mean value for their age is 34.2. From the total of 231 respondents who participated in this study, $55.0 \%$ were 19 to 33 years old, $32.5 \%$ between 34 and 48 and finally $12.5 \%$ were above the age of 49 . The youngest respondent was 19 and the oldest was 62 . The results showed that the number of female respondents was slightly higher. In fact, $58 \%$ of the respondents were female, whereas $42 \%$ were male. Based on Table 6 , the majority of the studied journalists were well educated with an academic background: $73.2 \%$ had completed a Degree, $14.3 \%$ had a Diploma and $5.1 \%$ had a Masters or PhD qualification. Among the 231 journalists, only 7.4\% had SPM (in English: Malaysia Certification of Education) (3.9\%) or STPM (in English: Malaysia Higher School Certification) (3.5\%).

Table 1. Profile of respondents

\begin{tabular}{lccc}
\hline Profile & & Frequency & Percentage \\
\hline Age & $19-33$ & 127 & 55.0 \\
$(\mathrm{n}=231)$ & $34-48$ & 75 & 32.5 \\
$($ Mean=34.2) & $49-62$ & 29 & 12.5 \\
Gender & Female & 134 & 58.0 \\
$(\mathrm{n}=231)$ & Male & 97 & 42.0 \\
Education & SPM & 9 & 3.9 \\
$(\mathrm{n}=231)$ & STPM & 8 & 3.5 \\
& Diploma & 33 & 14.3 \\
& Degree & 169 & 73.2 \\
& Master/ PhD & 12 & 5.1
\end{tabular}




\section{Field of Study}

$(\mathrm{n}=220)$

\section{Year of Experience}

$(\mathrm{n}=231)$

(Mean=9.7)

Position

$(\mathrm{n}=231)$

$\begin{array}{ccc}\text { Journalism/Media } & 143 & 65.0 \\ \text { Other fields } & 77 & 35.0 \\ \text { Less than 10 Years } & 146 & 63.2 \\ \text { More than 20 Years } & 85 & 36.8 \\ & & \\ \text { Reporter } & 162 & 70.1 \\ \text { Editor/Writer } & 46 & 19.9 \\ \text { Sub-editor } & 14 & 6.1 \\ \text { Chief-Editor } & 1 & 0.4 \\ \text { Others } & 8 & 3.5\end{array}$

The results indicated that the majority of the respondents had studied journalism or media studies $(65 \%)$. In fact, from 220 respondents, only $35 \%$ had studied in unrelated fields, such as science, engineering, art, or other social sciences fields. Journalism is a sector that people with a variety of different educational background can be employed in. In fact, there are many examples of self-taught journalists among the well-known successful ones around the world. The point is, in academic schools, journalism students become familiar with not only the skills of journalism, but also the theories and trends of the field. Journalism ethics is one of the inseparable courses in journalism in almost every college and university. The positive point is those Malaysian journalists who work in mainstream and high-circulation newspapers are among well-educated people who have related academic background.

In terms of work experience, most of the respondents had worked around 10 years in the field of journalism. In fact, almost two third of the 231 respondents $(63.2 \%)$ had less than 10 years of experience while $36.8 \%$ had an experience of more than 10 years (Table 1). Among them, $70.1 \%$ worked as reporters, $19.9 \%$ as editors or writers and the rest worked as sub-editor $(6.1 \%)$, chief-editor $(0.4 \%)$ or were employed in other positions $(3.5 \%)$.

\subsection{Ethical Decision Making}

The first objective of the study was to find out how well the journalists' decision making is in uncertain ethical situations. To achieve this objective, seven short presumptive statuses were designed based on the Malaysian National Union of Journalists' codes of ethics. For this section the Likert Scale question style was used, while the highest and lowest scores were 4 and 1 respectively. So, the maximum and minimum possible scores were 28 ( 7 x 4$)$ and 7 ( 7 x 1) respectively. Table 2 presented the results after summing the scores and categorizing them under two groups of "unfair" and "fair", based on the mean value.

Table 2. Journalists' ethical decision making $(\mathrm{n}=228)$

\begin{tabular}{lcc}
\hline Ethical Decision Making & Frequency & Percentage \\
\hline Unfair & 118 & 51.8 \\
(less than 20) & & \\
Fair & 110 & 48.2 \\
(More than 20) & & \\
\hline
\end{tabular}

Mean=20.42, Min=14, Max=26

Table 2 depicted that there was not a noticeable difference between the number of respondents under unfair and fair group. In fact, almost half (51.8\%) of the 228 journalists made unfair decisions, while $48.2 \%$ made fair decision. According to this table, the mean value of 7 questions, with a score varying between 1 and 4 , was 20.42 . The maximum achieved score was 26 , which was 2 points lower than the possible maximum. It means none of the journalists answered all the 7 questions correctly. Next table presented the detailed descriptions of ethical decision making's items (questions). According to Table 3, the overall mean value of all responses was 2.91 out of 4 with a standard deviation of 0.70 . The standard deviation of this section was appropriately dispersed from the mean value since it is within $+/-1$. 
Table 3. Detailed description of ethical decision making items

\begin{tabular}{|c|c|c|c|c|c|c|}
\hline Ethical Decision Making Items & Mean & Std & SA & $\mathbf{A}$ & D & SD \\
\hline $\begin{array}{l}\text { a. A car factory manufactures a new product. The journalist } \\
\text { knows that the car consumes high amount of petrol and has } \\
\text { also some technical problems. The manager offers him } 50 \% \\
\text { discount for a new car, asking him not to mention this } \\
\text { problem in his report. The journalist accepted the offer. He } \\
\text { believes people will find out the technical problem anyway. }\end{array}$ & 3.37 & 0.73 & $\begin{array}{c}6 \\
(2.6 \%)\end{array}$ & $\begin{array}{c}17 \\
(7.4 \%)\end{array}$ & $\begin{array}{c}91 \\
(39.6 \%)\end{array}$ & $\begin{array}{c}116 \\
(50.4 \%)\end{array}$ \\
\hline $\begin{array}{l}\text { b. A person in authority agrees to give some exclusive and } \\
\text { important information to a journalist under the condition of } \\
\text { being anonymous. But the journalist thinks it is people's right } \\
\text { to know who gave him those important information, so he has } \\
\text { revealed the source's name. }\end{array}$ & 3.12 & 0.85 & $\begin{array}{c}12 \\
(5.2 \%)\end{array}$ & $\begin{array}{c}36 \\
(15.7 \%)\end{array}$ & $\begin{array}{c}94 \\
(40.8 \%)\end{array}$ & $\begin{array}{c}88 \\
(38.3 \%)\end{array}$ \\
\hline $\begin{array}{l}\text { c. After publishing a good read story, the journalist finds out } \\
\text { some of his facts and information were basically inaccurate. } \\
\text { Although no complaints were received, he has decided to } \\
\text { rectify it by publishing a corrigendum (correction note) }\end{array}$ & 3.10 & 0.60 & $\begin{array}{c}53 \\
(23.0 \%)\end{array}$ & $\begin{array}{c}150 \\
(65.2 \%)\end{array}$ & $\begin{array}{c}25 \\
(10.9 \%)\end{array}$ & $\begin{array}{c}2 \\
(0.9 \%)\end{array}$ \\
\hline $\begin{array}{l}\text { d. A journalist has published a story which causes many } \\
\text { arguments among different points of views. He decided to } \\
\text { publish only comments and critics which were fair, respectful } \\
\text { and polite. }\end{array}$ & 3.09 & 0.68 & $\begin{array}{c}29 \\
(12.7 \%)\end{array}$ & $\begin{array}{c}121 \\
(52.8 \%)\end{array}$ & $\begin{array}{c}62 \\
(27.1 \%)\end{array}$ & $\begin{array}{c}17 \\
(7.4 \%)\end{array}$ \\
\hline $\begin{array}{l}\text { e. To write a report about illegal workers, a journalist found } \\
\text { different facts and statistics from different sources. Then he } \\
\text { has decided to publish the facts and statistics which he } \\
\text { personally knows the origin well. }\end{array}$ & 2.75 & 0.64 & $\begin{array}{c}10 \\
(4.2 \%)\end{array}$ & $\begin{array}{c}54 \\
(23.8 \%)\end{array}$ & $\begin{array}{c}122 \\
(53.6 \%)\end{array}$ & $\begin{array}{c}42 \\
(18.4 \%)\end{array}$ \\
\hline $\begin{array}{l}\text { f. A journalist has been assigned to write a report about } \\
\text { conflict between two groups of A and B. He found that people } \\
\text { in group B are right because his friends and family members } \\
\text { were in group B and they told him the truth. He considers } \\
\text { their information "first-hand" and he reported the conflicts } \\
\text { based on that. }\end{array}$ & 2.70 & 0.78 & $\begin{array}{c}61 \\
(26.6 \%)\end{array}$ & $\begin{array}{c}134 \\
(58.5 \%)\end{array}$ & $\begin{array}{c}29 \\
(12.7 \%)\end{array}$ & $\begin{array}{c}5 \\
(2.2 \%)\end{array}$ \\
\hline $\begin{array}{l}\text { g. A journalist has published some documents and facts which } \\
\text { he found through spying the private life of a candidate for } \\
\text { election. The journalist believes people should realize that the } \\
\text { candidate has been unfaithful to people; that's why he has } \\
\text { published the information. }\end{array}$ & 2.22 & 0.68 & $\begin{array}{c}27 \\
(11.8 \%)\end{array}$ & $\begin{array}{c}130 \\
(56.8 \%)\end{array}$ & $\begin{array}{c}65 \\
(28.4 \%)\end{array}$ & $\begin{array}{c}7 \\
(3.0 \%)\end{array}$ \\
\hline Overall & 2.91 & 0.70 & & & & \\
\hline
\end{tabular}

$\mathrm{SA}=$ Strongly Agree, $\mathrm{A}=$ Agree, $\mathrm{D}=$ Disagree, $\mathrm{SD}=$ Strongly Disagree

As it was mentioned before, each question of this section was based on one of the NUJ's codes of ethics. For instance, 'Item a', which had the highest mean value (3.37 from 4), examined the NUJ $7^{\text {th }}$ codes of ethics. It is clearly mentioned in NUJ $7^{\text {th }}$ codes of ethics that 'the acceptance of bribe in any form in consideration of either publication or suppression is unethical'. Based on Table 3, 50.4\% of journalists strongly disagreed and $39.6 \%$ disagreed that accepting bribe is tolerable. The mean value was very close to 4 and the obtained result proved 
that journalists were quite aware of this unethical journalism decision.

The second highest mean value was obtained for 'Item b'. This item questioned the NUJ $6^{\text {th }}$ codes of ethic which clearly said that "journalists should observe professional secret regarding the source of information obtained in confidence". The mean value for this Item was 3.12 out of 4 . Based on Table 3, a noticeable number of journalists disagreed (40.8\%) or strongly disagreed (38.3\%) that revealing the name of an information source which was asked to be anonymous is permissible. It means journalists were aware of this ethical issue and will possibly behave ethically if they face such an uncertain situation in real world.

The third highest mean value item in Table 3 was 'Item c' with the mean value of 3.10 out of 4 . This item questioned the NUJ $5^{\text {th }}$ codes of ethics which said: "journalists should do their utmost to rectify any published information which is found to be harmfully inaccurate"; $65.2 \%$ of journalists agreed and $23 \%$ strongly agreed that a journalist should publish a corrigendum if they found that there were some inaccurate facts in their published story.

The mean value of the next item (Item d) was 3.09 as shown in Table 3. The journalists were asked if "they agreed to publish only fair, respectful and polite comments and critics regarding to a controversial story"; a considerable number of the respondents agreed $(52.8 \%)$ or strongly agreed $(12.7 \%)$. However, a sizable percent of journalists $(27.1 \%)$ disagreed with this ethical behavior.

The last three items scored a mean value of less than 3, meaning that the responses were unfair. According to the Table, 'Item e' which was based on the NUJ $3^{\text {rd }}$ codes of ethics, scored a mean value of 2.75 . Based on the codes, "journalists should record only in accordance with the facts of which they know the origin and should not suppress essential information or falsify documents". The low mean value clarified that the journalists will possibly behave unfairly when facing similar dilemmas and may publish the information without verifying the source. In fact, based on Table 3, 53.6\% of journalists disagreed and $18.4 \%$ strongly disagreed that a journalist should publish the facts and statistics which they personally know their origin well.

Another item which received unfair responses was 'Item f' with the mean value of 2.70. This item was about objectivity and respecting the truth. In a given scenario the necessity of objectivity in collecting information for news was questioned; more than half of the journalists gave unfair responses. They mostly (58.5\%) agreed or strongly agreed $(26.6 \%)$ that covering a conflict between two groups based on the information provided by one of them is permissible, whereas the journalism codes of ethics considers such behavior as biased.

The lowest mean value of 2.22 was obtained in 'Item g'. This item was based on NUJ $4^{\text {th }}$ codes of ethics which said "journalists should only use fair methods to obtain news, photographs and documents". Based on the results, the majority of journalists (56.8\%) believed that obtaining information by spying is legitimate if the information is important for public.

In summary, the results of the three last items showed that the journalists were not aware of some crucial ethical principals in journalism, which have been clearly mentioned in the NUJ codes of ethics such as: objectivity, using fair methods in obtaining news and publishing only fair and polite comments or critics.

\subsection{Gender, Journalism Education}

The second objective of this study was to determine if the journalists' gender and journalism education affects their ethical decision making. To achieve this objective independent sample t-test was applied to analyze the mean comparison of two independent groups. According to Table 4, $t$ value for gender with freedom degree of 226 was 1.7 , while the $p$ value was 0.08 . It means there was no significant difference between journalists' gender, whether male or female, with their decision making as the $\mathrm{p}$ value was not significant. In other words, the gender of 96 male and 132 female journalists who participated in this survey did not have a role in their decision making in uncertain ethical situations.

According to this Table, $t$ value of education with freedom degree of 215 was 1.2 while the $p$ value was 0.2 . Therefore, since the $\mathrm{p}$ value was more than 0.05 , there was no significant difference in decision making of 141 journalists who studied journalism and 76 who studied in other fields. In summary, neither the gender nor journalism education made differences in journalists' ethical decision making in uncertain situations. 
Table 4. Gender, education and ethical decision making independent sample t-test

\begin{tabular}{|c|c|c|c|c|c|c|c|}
\hline & & $\mathbf{N}$ & Mean & Std Davison & $t$ & df & $p$ \\
\hline \multirow[t]{2}{*}{ Gender } & Male & 96 & 20.7 & 2.9 & \multirow{2}{*}{1.7} & \multirow{2}{*}{226} & \multirow{2}{*}{0.08} \\
\hline & Female & 132 & 20.2 & 2.1 & & & \\
\hline \multirow[t]{2}{*}{ Field of Study } & Journalism & 141 & 20.5 & 2.5 & \multirow{2}{*}{1.2} & \multirow{2}{*}{215} & \multirow{2}{*}{0.2} \\
\hline & Others & 76 & 20.1 & 2.0 & & & \\
\hline
\end{tabular}

\subsection{Work Experience}

The last objective of this study was to determine the relationship between journalists' work experience and their ethical decision making in uncertain situations. According to Table 5, most journalists (86 respondents out of 144) who had less than 10 years of work experience were categorized under unfair ethical decision makers while most of the journalists (52 respondents out of 84) who had more than 10 years of experience were fair ethical decision makers. The Chi-square test which was applied in this table revealed that there was a significant difference between journalists' work experience and their ethical decision making $\left(\chi^{2}=8.55, \mathrm{p}=0.00\right)$. It means journalists who had more experience, made more fair ethical decisions in uncertain situations.

Table 5. Work experience and ethical decision making cross tabulation

\begin{tabular}{lcc}
\hline & \multicolumn{2}{c}{ Ethical Decision Making } \\
\hline Work Experience & Unfair $(\mathbf{n}=\mathbf{1 1 8})$ & Fair $(\mathbf{n}=\mathbf{1 1 0})$ \\
Less than $10(\mathrm{n}=144)$ & 86 & 58 \\
More than $10(\mathrm{n}=84)$ & 32 & 52 \\
\hline$\chi^{2}=8.55, p=0.00$ & &
\end{tabular}

For the above-mentioned objective, the Bivariate Pearson was also used to test the correlations between journalists' work experience and their ethical decision making. The Pearson correlation coefficient (r) measures how closely related the two variables are. The result was presented in Table 6. According to this Table, there was a significant correlation between journalists' work experience and their ethical decision $(p=0.002)$. However, the Pearson correlation (r) coefficient was 0.209 . Based on the rule of thumb, suggested by Guilford and Fruchter (1973), there was a slight relationship between journalists' work experience and ethical decisions.

Table 6. Bivariate pearson correlation between work experience and ethical decision making

Ethical Decision Making

Pearson Correlation ( $r$ )

Sig (2-tailed)

$\begin{array}{lll}\text { Work Experience } & 0.209 & 0.002\end{array}$

As it was mentioned earlier in the literature review, various journalism ethics studies have attempted to link internal influences such as personal values and beliefs, education, experience, journalism training, age and gender with ethical behavior or decision-making, but the results of the current study showed that there was no significant difference in journalists' ethical decision based on their gender and journalism education. Meanwhile journalists' work experience had a slight relationship in improving their ethical decisions.

In Malaysia, like many other Asian countries, journalists mostly do not make decisions individually in uncertain situations. Since their media organizations belong to the government - directly or indirectly - they hardly get involved in common challenging journalistic situations. So despite the high number of well-educated journalists in this country, the room for real journalism practices is limited. The results of a study about journalism in Indonesia, done by Hanitzsch (2005), also revealed that journalists in that country see themselves as neutral and objective disseminators of news, not as political actors and agents of development. Hanitzsch (2005) noted that although his study's primary focus was on Indonesia, the analysis goes well beyond national boundaries in Asia. 


\section{References}

Adam, A. M., \& Rachman-Moore, D. (2004). The methods used to implement an ethical code of conduct and employee attitude. Journal of Business Ethics, 54(3), 225-244. http://dx.doi.org/10.1007/s10551-004-1774-4

Banerjee, I. (2002). Media ethics in Malaysia. Critical issues and perspectives. In V. Iyer (Ed.), Media ethics in Asia. Addressing the dilemma in the information age (pp. 66-79). Singapore: AMIC and NTU.

Beam, R. A. (1990). Journalism professionalism as an organizational-level concept. Journalism Monographs, $121,1-43$.

Berkowitz, D., Limor, Y., \& Singer, J. (2004). A cross-cultural look at serving the public interest: American and Israeli journalists consider ethical scenarios'. Journalism, 5(2), 159-181. http://dx.doi.org/10.1177/146488490452001

Boone, L., \& MacDonald, C. (2009). Broadcasting operation Iraqi freedom: the people behind cable news ethics, decisions and gender differences. Journal of Business Ethics, 85(1), 115. http://dx.doi.org/10.1007/s10551-008-9687-2

Breed, W. (1955). Social control in the newsroom. Journal of Social Forces, 33(4), 326-335. http://dx.doi.org/10.2307/2573002

Chonko, L., Wotruba, T., \& Loe, T. (2003). Ethics code familiarity and usefulness: Views on idealist and relativist managers under varying conditions of turbulence. Journal of Business Ethics, 42, 237-252. http://dx.doi.org/10.1023/A:1022261006692

Cohen, J. R., Pant, L. W., \& Sharp, D. J. (1998). The effect of gender and academic discipline diversity on the ethical evaluations. Accounting Horizons, 3(12), 250-270.

Deuze, M. (2005). What is journalism? Professional identity and ideology of journalists reconsidered. Journalism, 6(4), 442-464. http://dx.doi.org/10.1177/1464884905056815

Faridah Ibrahim, F. (2010). Press freedom and ethics with accountability: premised and constraints. Paper presented at International Conference cum workshop on free and responsible journalism. Malaysia, Port Dickson. $\quad$ Retrieved $\quad$ September $12, \quad 2012, \quad$ from http://www.ssig.gov.my/ssig/kcent/material/1-PRESS\%20FREEDOM\%20\%20SSIG-\%20dr\%20faridah[1]. $\mathrm{pdf}$

Fisher, N. (2001). Managers' perceptions of ethical codes: Dialectics and dynamics. Business Ethics A European Review, 10(2), 145-156. http://dx.doi.org/10.1111/1467-8608.00225

Graber, D. (1997). Mass media and American politics (5th ed.). Washington, D.C.: Congressional Quarterly Press.

Guilford, J, P., \& Fruchter, B. (1973). Fundamental statistics in psychology and education (6th ed.). New York: Mc Graw Hill.

Hanitzsch, T. (2005). Journalists in Indonesia: educated but Timid Watchdogs. Journalism Studies, 6(4), 493-508. http://dx.doi.org/10.1080/14616700500250396

Hoo, Q. C., \& Yeing, L. S. (2010). Ethics code awarenedd, usefulness and professionalism of Malaysian journalists. Journal of Business System, Government and Ethics, 5(2), 31-42.

Joyner, B. E., \& Payne, D. (2002). Evolution and implementation: a study of values, business ethics and corporate social responsibility. Journal of Business Ethics, 41(4), 297-312. http://dx.doi.org/10.1023/A:1021237420663

Kaptein, M. (2004). Business codes of multi-national firms. What do they say? Journal of Business Ethics, 50(1), 13-31. http://dx.doi.org/10.1023/B:BUSI.0000021051.53460.da

Kaur, K., \& Shaari, H. (2003). Ethical practices of communication practitioners in Malaysia. Retrieved Sepember 12, 2012, from http://eprints.uitm.edu.my/3617/1/LP_KRANJIT_KUAR_03_24.pdf

Kohlberg, L. (1981). The meaning and measurement of moral development. Cambridge, UK: Oelgeschlager.

Leban, V., \& Kovacic, M. (2007). Editors' Perceptions and Attitudes towards Professional Competence, Ethics and their Understanding of Journalism: the case of Slovenia. Paper presented at the 2007 IAMCR Conference, UNESCO, Paris.

Mason, S., \& Mudrack P. E. (1996). Gender and ethical orientation: a test of gender and occupational 
socialization theories. Journal of Business Ethics, 15(6), 599-604. http://dx.doi.org/10.1007/BF00411793

Motlagh, N. E., \& Ismail, N. (2009). Perception of journalism ethics among Malaysian journalists. Paper presented at the Pacific \& Asian Communication Assosiation (PACA 2009), Communication Department-University Putra Malaysia (January).

O'Dwyer, B., \& Madden, G. (2006). Ethic codes of conducts in Irish companies: A survey of code content and enforcement procedures. Journal of Business Ethics, 63, 217-236. http://dx.doi.org/10.1007/s10551-005-3967-x

Peterson, D., Rhoads, A., \& Vaught, B. C. (2001). Ethical beliefs of business professional: a study of gender, age and external Factors. Journal of Business Ethics, 31(3), 225-232. http://dx.doi.org/10.1023/A:1010744927551

Pyle, C. H. (2000). Irresponsible journalists are jeopardizing serious Investigations by the Press. The Chronicle of Higher Education, 46(18), 9-10.

Rothman, R. A. (1984). Deprofessionalization: The case of law in America. Work and Occupations, 11(2), 183-206. http://dx.doi.org/10.1177/0730888484011002004

Sanders, K. (2003). Ethics \& journalism. London, Thousand Oaks, New Delhi: Sage Publications.

Schwartz, M. (2000). Why ethical codes constitute an unconscionable regression. Journal of Bussiness Ethics, 23(2), 174-184. http://dx.doi.org/10.1023/A:1006151806232

Somers, M. J. (2001). Ethical codes of conduct and organizational context: A study of the relationship between codes of conducts, employee behavior and organizational values. Journal of Business Ethics, 30(2), 185-195. http://dx.doi.org/10.1023/A:1006457810654

Stevens, B. (2008). Corporate ethical codes: Effective instrument for influencing behavior. Journal of Business Ethics, 78, 601-660. http://dx.doi.org/10.1007/s10551-007-9370-z

Tanner, S., Phillips, G., Smyth, C., \& Tapsall, S. E. (2005). Journalism ethics and work. Sydney: Pearson Education Australia.

Valenti, J. M. (1998). Ethical decision making in environmental communication. Journal of Mass Media Ethics, 13(4), 219-231. http://dx.doi.org/10.1207/s15327728jmme1304_2

Vittell, S., \& Encarnacion, R. (2006). The impact of corporate ethical values and enforcement of ethical codes on the perceived importance of ethics in business: A comparison of U.S. and Spanish managers. Journal of Business Ethics, 64(1), 31-43. http://dx.doi.org/10.1007/s10551-005-4664-5

Voakes, P. S. (1997). Public perception of journalists' ethical motivations. Journalism and Mass Communication Quarterly, 74(1), 23-38. http://dx.doi.org/10.1177/107769909707400103

Weaver, D. H., \& Wilhoit, C. G. (1996). The American journalist: A portrait of U.S. news people and their work. Bloomington: Indiana University Press.

Weeks, W. A., Moore, C. W., McKinney, J. A., \& Longenecker, J. G. (1999). The effects of gender and career stage on ethical judgment. Journal of Business Ethics, 20(4), 301-313. http://dx.doi.org/10.1023/A:1005955501120

Wong, K. (2004). Asian-based development journalism and political elections: Press coverage of the 1999 General Election in Malaysia. Gazette, 66(1), 25-40.

Wotruba, T., Chonko, L., \& Loe, T. (2001). The impact of ethics code familiarity on manager behaviour, Journal of Business Ethics, 33(1), 59-69. http://dx.doi.org/10.1023/A:1011925009588

Wulfemeyer, K. (1990). Defining ethics in electronic journalism: perceptions of news directors. Journalism Quarterly, 67, 984-991. http://dx.doi.org/10.1177/107769909006700454

Yamane, T. (1967). Statistics, an introductory analysis (2nd ed.). New York: Harper and Row.

\section{Copyrights}

Copyright for this article is retained by the author(s), with first publication rights granted to the journal.

This is an open-access article distributed under the terms and conditions of the Creative Commons Attribution license (http://creativecommons.org/licenses/by/3.0/). 